\title{
KARAKTERISTIK SOSIS BERBAHAN BAKU CAMPURAN JAMUR TIRAM PUTIH (Pleurotus ostreatus) DAN OTAK SAPI
}

Characteristics of Sausages Made from the Mixture of Oyster Mushrooms (Pleurotus ostreatus) and Cow's Brain

\author{
Fiola Hamanda Prisilia ${ }^{1)}$, Yhulia Praptiningsih ${ }^{1)}$, Riska Rian Fauziah $^{1 \text { ** }}$ \\ ${ }^{1)}$ Jurusan Teknologi Hasil Pertanian, Fakultas Teknologi Pertanian, Universitas Jember \\ J1. Kalimantan 37, Kampus Tegal Boto Jember 68121 \\ *E-mail : fauziah.rr@gmail.com
}

\begin{abstract}
Sausage is a processed product which have meat as its main ingredients and the extender ingredients are binders, filler, sugar, salt and also seasoning then mixed and put it into a casing. Commonly sausage use meat as its raw ingredient.The expensive price of meat will cause the price of sausage also increasing, so then an innovation to use another main ingredients as the alternative of meat that is cheaper, such as white oyster mushroom. Oyster mushroom have protein and fiber but also contain low level of fat, so it need to increase of fat content by cow's brain. Cow's brain have high of fat content so that it will be useful to increase the fat content in the oyster mushroom mixed with cow brain sausage. The purpose of this experiment is to find the right ratio in the process of mixing white oyster mushroom with cow brain. This experiment was conducted by the Complete Randomized Design. The treatment was ratio of oyster mushroom and cow brain it had 5 levels. The oyster mushroom and cow brain ratio are P1 (90:10); P2 (80:20); P3 (70:30); P4 (60:40); P5(50:50). The parameter of the observation are texture, colour, cooking loss, apperance of the slice, moisture content, fat content, and sensoric properties was the preference of colour, flavour, texture, taste and overall. The best treatment was analysis of proximate test. Based on effectiveness test from this research, the best formulation was on P5 treatment (oyster mushroom and cow meat ratio 50:50). The sausage had score of texture of $63 \mathrm{~g} / 1,5 \mathrm{~mm}$; color 57,59; cooking loss 7,11\%; moisture content 60,31\%; fat content 4,22\%; protein content 21,05\%; ash content 2,08\%; carbohydrate content 12,34\%; preference of colour, smell, texture, taste and overall was 5,7; 6,36; 5,36; 5,75; 5,92 (neutral- a bit of contentment).
\end{abstract}

Keywords: sausage, oyster mushrooms, cow's brain, ratio

\section{PENDAHULUAN}

Tingkat konsumsi sosis di Indonesia pada tahun 2013 sebesar 2,2 gram/kapita/tahun dan diperkirakan akan terus meningkat (Chandra, 2015). Sosis merupakan produk emulsi minyak dalam air dengan komposisi yang terdiri dari protein hewani, bahan pengisi, bahan pengikat dan bumbu-bumbu dan termasuk jenis frozen food. Kandungan protein sosis berdasarkan SNI minimal $13 \%$ dan kandungan lemak maksimal sebesar 25\% (Badan Standar Nasional, 1995). Pada umumnya, sosis terbuat dari protein hewani seperti daging sapi. Daging sapi mengandung protein sebesar 16-22\%, namun harga daging sapi yang mahal menyebabkan harga jual sosis daging sapi mahal. Salah satu alternatif bahan baku pembuatan sosis untuk mengurangi biaya produksi adalah jamur tiram putih.

Jamur tiram putih merupakan salah satu jenis jamur tiram yang dapat dikonsumsi. Produksi jamur tiram di Indonesia pada tahun 2011 sebesar 43.047.029 kg dan diperkirakan permintaan jamur terus meningkat setiap tahun sekitar 20-25\% (Maulana, 2013). Jamur tiram putih mengandung protein $3,4 \%$; lemak $0,68 \%$; air $86 \%$; dan serat $3,4 \%$ (Lee, 2008). Kandungan air yang cukup tinggi pada jamur tiram akan 
mempersingkat daya simpan, sehingga diperlukan pengolahan agar memperpanjang daya simpan jamur tiram seperti sosis. Kandungan protein dan serat pada jamur tiram yang menyerupai daging dapat dimanfaatkan menjadi bahan baku sosis, namun kandungan lemak jamur tiram rendah. Menurut SNI 01-3820 (Badan Standar Nasional, 1995) kandungan lemak sosis maksimal 25\%, sehingga dalam pembuatan sosis diperlukan penambahan lemak. Salah satu bahan pangan yang mengandung lemak tinggi yaitu otak sapi.

Otak sapi merupakan bagian edible by product yang dapat dimanfaatkan menjadi produk aneka ragam dari daging. Otak sapi mengandung protein $10,4 \%$ dan lemak $8,6 \%$ (Nio, 2012). Pada otak sapi mengandung fosfolipid sebesar $83 \%$ dari total lemak otak (Anderson, 1983). Fosfolipid memiliki kemampuan sebagai emulsifier, sehingga dapat memperbaiki produk emulsi seperti sosis (Jensen, 1958).

Sosis dengan bahan baku jamur tiram putih dan otak sapi harus memiliki sifat baik agar dapat diterima oleh konsumen. Menurut SNI 01-3820-1995 kandungan protein minimal $13 \%$, lemak maksimal 25\%, dan air 67\%. Sosis dengan sifat-sifat baik dapat diperoleh dengan melakukan pengaturan rasio antara jamur tiram putih sebagai sumber protein dan serat dan otak sapi sebagai sumber lemak. Oleh karena itu, dilakukan penelitian yang bertujuan untuk mengetahui rasio yang tepat pada pembuatan sosis campuran jamur tiram putih dan otak sapi.

\section{METODE PENELITIAN}

\section{Alat dan Bahan}

Alat yang digunakan dalam pembuatan sosis yaitu food processor philips, neraca analitik ohaus ex 124/AD dan memmert waterbath. Alat yang digunakan dalam analisis yaitu neraca analitik, oven memmert, botol timbang, penjepit, eksikator plat keramik duran, alat-alat gelas, pi-pump glasfirn, labu kjeldahl pyrex, destilator unit K-350, labu lemak, kurs porselin, tanur furnace $\mathrm{f} 48010$, rheotex SD-70011, dan colour reader CR-10.

Bahan baku pembuatan sosis yaitu jamur tiram putih, otak sapi, bawang putih, lada, pala, selongsong selulosa, gula, garam dan minyak kelapa sawit. Bahan kimia yang digunakan antara lain aquadest, $\mathrm{H}_{2} \mathrm{SO}_{4}$, asam borat $4 \%$, indikator $\mathrm{pp}, \mathrm{HCl}$ $0,02 \mathrm{~N}$, benzena, $\mathrm{NaOH} 0,1 \mathrm{~N}$, kertas saring dan selenium.

\section{Tahapan Penelitian}

Pembuatan sosis campuran jamur tiram dan otak sapi

Pada proses pembuatan sosis jamur tiram, pertama jamur tiram segar dilakukan proses pengolahan menjadi pasta jamur tiram. Jamur tiram dilakukan penyiangan yang bertujuan untuk mengambil bagian jamur yang dapat dikonsumsi. Bagian jamur yang dapat dikonsumsi lalu dilakukan pencucian dengan air mengalir yang bertujuan untuk menghilangkan kotoran. Bagian Jamur yang bersih lalu ditiriskan. Penirisan bertujuan untuk mengurangi air. Setelah bersih, jamur dilakukan blanching dengan cara perebusan yang bertujuan untuk menonaktifkan enzim. Bagian jamur tiram putih yang telah di blanching dilakukan pengecilan ukuran menggunakan food processor sehingga dihasilkan pasta jamur tiram putih.

Otak sapi dibersihkan dari kotoran dan darah. Otak sapi yang bersih dilakukan pengecilan ukuran sehingga dihasilkan pasta otak sapi. Bumbu yang digunakan meliputi pala, lada, bawang putih, garam dan gula pasir. Bawang putih dilakukan penghilangan kulit. Setelah dilakukan penghilangan kulit lalu dilakukan penghalusan. Penambahan bumbu berdasarkan berat campuran jamur tiram dan otak sapi. Lada sebesar $0,42 \%$; pala $0,42 \%$; bawang putih $2,5 \%$; gula $1 \%$; dan gram 3\%. Bumbu, pasta otak sapi, pasta jamur, tepung terigu $20 \%$, isolat protein kedelai $20 \%$ dan minyak $2 \%$ dilakukan pencampuran agar adonan homogen. 
Adonan homogen dimasukkan ke dalam selongsong sosis selulosa dengan ukuran diameter 18,45 $\mathrm{mm}$ dengan panjang $10 \mathrm{~cm}$ dan berat \pm 15 gram. Sosis dimasak dengan cara dikukus dengan suhu $100^{\circ} \mathrm{C}$ selama 45 menit. Setelah sosis dimasak selanjutnya didinginkan.

\section{Rancangan Percobaan}

Penelitian ini menggunakan metode Rancangan Acak Lengkap (RAL) dengan 5 perlakuan yaitu rasio jamur tiram dan otak sapi. Perlakuan tersebut antara lain P1 (90:10); P2 (80:20); P3 (70:30); P4 (60:40) dan P5 (50:50).

\section{Metode Analisis}

Pengujian analisis sosis meliputi uji fisik, kimia dan organoleptik. Parameter uji fisik meliputi tekstur, warna, cooking loss, dan kenampakan irisan. Parameter uji kimia meliputi kadar air dan kadar lemak. Parameter uji organoleptik meliputi kesukaan warna, aroma, tekstur, rasa dan kesukaan keseluruhan). Perlakuan terbaik (sampel sosis terbaik) kemudian dilakukan uji proksimat (uji kadar protein, abu dan karbohidrat). Pengujian fisik meliputi tekstur menggunakan rheotex, warna menggunakan colour reader, cooking loss menggunakan metode penurunan berat (Cakli et al., 2015), dan kenampakan irisan menggunakan metode pemotretan. Pengujian kimia meliputi kadar air menggunakan metode thermogravimetri (AOAC, 2005) dan kadar lemak menggunakan metode soxhlet (AOAC, 2005). Pengujian organoleptik menggunakan uji kesukaan (Mabesa, 1986).

Data diolah dengan analisis sidik ragam (ANOVA). Jika terdapat beda nyata maka dilanjutkan dengan uji Duncan's Multiple Range Test (DMRT) pada taraf uji 5\%. Pemilihan perlakuan terbaik menggunakan metode efektivitas (De Garmo et al., 1994).

Sosis dengan perlakuan terbaik dilakukan uji proksimat meliputi kadar air metode thermogravimetri (AOAC, 2005), kadar lemak metode soxhlet (AOAC, 2005), kadar protein metode kjeldahl (AOAC, 2005), kadar abu metode langsung (AOAC, 2005), dan kadar karbohidrat metode carbohydrate by difference (AOAC, 2005).

\section{HASIL DAN PEMBAHASAN}

\section{Sifat Fisik Sosis \\ Tekstur}

Nilai tekstur sosis jamur tiram putih dan otak sapi berkisar $25 \mathrm{~g} / 1,5 \mathrm{~mm}$ $63 \mathrm{~g} / 1,5 \mathrm{~mm}$. Nilai tertinggi pada perlakuan P5 (rasio penambahan jamur tiram putih dan otak sapi $=50: 50$ ) menunjukkan semakin keras. Nilai terendah pada P1 (rasio penambahan jamur tiram putih dan otak sapi $=90: 10$ ) menunjukkan semakin lunak. Berdasarkan analisis ragam pada taraf 5\% dapat diketahui bahwa rasio antara jamur tiram dan otak sapi berpengaruh nyata terhadap tekstur. Hasil analisis uji tekstur dapat dilihat pada

\section{Gambar 1.}

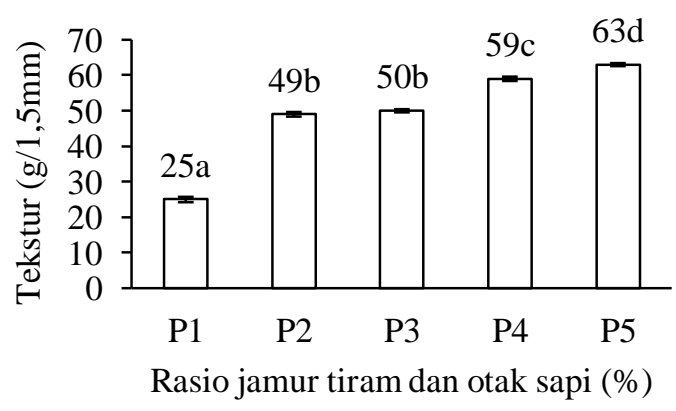

Gambar 1. Tekstur sosis campuran jamur tiram dan otak sapi. (Jamur tiram putih : Otak sapi; P1 = 90:10; P2 = 80:20; $\mathrm{P} 3=70: 30 ; \mathrm{P} 4=60: 40 ; \mathrm{P} 5=50: 50$ )

Pada Gambar 1 dapat diketahui bahwa semakin tinggi rasio otak sapi maka akan meningkatkan kekerasan tekstur sosis campuran jamur tiram dan otak sapi. Tekstur pada produk pangan dipengaruhi oleh kadar air, kadar lemak dan kadar serat (Aprliyani, 2010). Kandungan air pada 
jamur tiram putih lebih tinggi daripada otak sapi, sehingga semakin tinggi rasio otak sapi maka akan menurunkan kadar air (Gambar 5). Penurunan kadar air akan meningkatkan kekerasan pada sosis campuran jamur tiram putih dan otak sapi. Kadar air dalam produk dapat mempengaruhi kekerasan produk, semakin banyak air yang terkandung dalam produk maka kekerasannya menurun (Setyowati, 2002). Kandungan air pada jamur tiram yang lebih tinggi daripada otak sapi diduga akan menurunkan tingkat kekerasan pada sosis. Hal ini sesuai dengan penelitian Widati (2013), penambahan jamur tiram akan menurunkan kekerasan.

Kadar lemak akan mempengaruhi tekstur. Semakin tinggi otak sapi maka akan meningkatkan kandungan lemak pada sosis (Gambar 6). Kandungan lemak yang semakin tinggi akan meningkatkan kekerasan pada tekstur. Hal ini dikarenakan lemak mengandung kristal besar, kristal lemak akan membentuk jaringan tiga dimensi yang akan mengakibatkan kekakuan pada produk. Kristal terikat satu sama lain oleh gaya tarik menarik Van der Waals (DeMan, 1997). Semakin tinggi otak sapi maka akan meningkatkan kekerasan pada sosis campuran jamur tiram dan otak sapi.

Kandungan serat juga akan mempengaruhi tekstur. Semakin tinggi otak sapi maka akan menurunkan kandungan serat pada sosis. Kandungan serat larut pada jamur sebesar 4-9\% sedangkan serat tidak larut sebesar 22-30\% (Kalac, 2012). Jenis serat yang banyak terkandung pada jamur seperti kitin dan juga terdapat beberapa polisakarida lainnya seperti hemiselulosa dan pektik. Serat yang semakin tinggi akan mencegah hilangnya air. Hal ini dikarenakan serat akan meningkatkan kemampuan mengikat air sehingga kekerasannya menurun (Chatli et al., 2011).

\section{Warna (lightness)}

Hasil pengamatan tingkat kecerahan warna (lightness) sosis adalah 57,59-61,54. Nilai tertinggi lightness terdapat pada perlakuan P1 (rasio penambahan jamur tiram putih dan otak sapi 90:10). Nilai terendah lightness terdapat pada perlakuan sosis P5 (rasio penambahan jamur tiram putih dan otak sapi 50:50). Berdasarkan analisis ragam pada taraf $5 \%$ dapat diketahui bahwa rasio antara jamur tiram dan otak sapi berpengaruh nyata terhadap warna sosis. Nilai rata-rata kecerahan warna dapat dilihat pada Gambar 2.

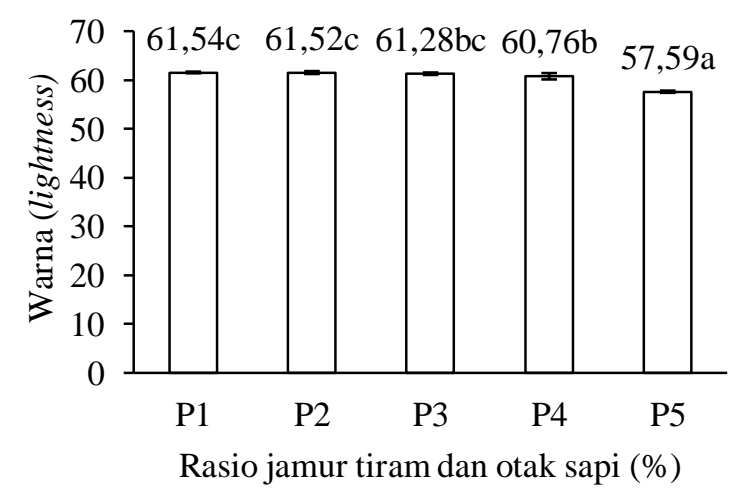

Gambar 2. Warna (lightness) sosis campuran jamur tiram dan otak sapi. (Jamur tiram putih : otak sapi; P1 = 90:10; $\mathrm{P} 2=80: 20 ; \mathrm{P} 3=70: 30 ; \mathrm{P} 4=$ $60: 40 ; \mathrm{P} 5=50: 50$ )

Pada Gambar 2 dapat diketahui bahwa semakin tinggi penambahan otak sapi maka akan menurunkan kecerahan sosis campuran jamur tiram dan otak sapi. Hal ini diduga karena pada otak sapi mengandung mioglobin. Mioglobin sebagai salah satu protein sarkoplasmik terbentuk dari suatu rantai polipeptida tunggal terikat di sekeliling suatu grup heme yang membawa oksigen (Soeparno, 2005). Kandungan mioglobin pada otak sapi sebesar $0,01 \%$ dari total kandungan protein dalam otak (Garry et al., 2002). Kandungan protein pada otak sapi sebesar $10,4 \%$. Semakin tinggi rasio otak sapi maka akan meningkatkan kandungan protein dan kandungan mioglobin. Mioglobin dapat teroksidasi pada suhu 80- 
$85^{\circ} \mathrm{C}$. Mioglobin jika teroksidasi akan membentuk metmioglobin yang menyebabkan warna coklat (Soeparno, 2005). Rasio otak sapi yang semakin tinggi akan menyebabkan semakin banyak mioglobin yang teroksidasi menjadi metmioglobin sehingga kecerahan sosis menurun.

\section{Cooking loss}

Hasil analisis cooking loss sosis berkisar 1,99-7,11\%. Cooking loss sosis tertinggi pada perlakuan P5 (rasio penambahan jamur tiram putih dan otak sapi 50:50). Nilai cooking loss terendah terdapat pada perlakuan P1 (rasio penambahan jamur tiram putih dan otak sapi 90:10). Berdasarkan analisis ragam pada taraf 5\% dapat diketahui bahwa rasio antara jamur tiram dan otak sapi berpengaruh nyata terhadap cooking loss sosis. Nilai rata-rata kadar cooking loss dapat dilihat pada Gambar 3.

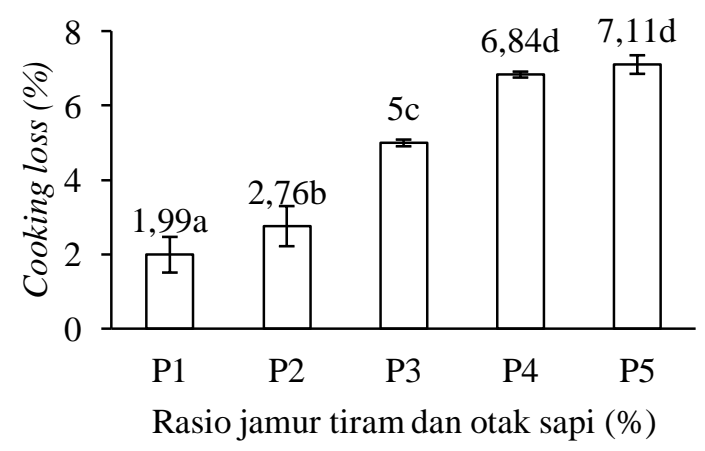

Gambar 3. Cooking loss sosis campuran jamur tiram dan otak sapi (Jamur tiram putih : Otak sapi; P1 = 90:10; P2 = 80:20; P3 $=70: 30 ; \mathrm{P} 4=60: 40 ; \mathrm{P} 5=50: 50$ )

Cooking loss adalah penyusutan berat selama pemasakan. Pada Gambar 3 dapat diketahui bahwa semakin tinggi rasio otak sapi maka meningkatkan cooking loss sosis campuran jamur tiram dan otak sapi. Cooking loss dipengaruhi oleh kadar lemak dan kadar serat. Kadar lemak akan mempengaruhi cooking loss. Semakin tinggi otak sapi maka akan meningkatkan kadar lemak (Gambar 6). Kemampuan mengikat air menurun seiring dengan peningkatan kandungan lemak sehingga semakin banyak air yang keluar bersama komponen yang larut dalam air (Chun, 2003) sehingga cooking loss pada sosis semakin meningkat.

Kandungan serat juga akan mempengaruhi cooking loss. Semakin tinggi otak sapi maka akan menurunkan kandungan serat pada sosis. Kandungan serat larut pada jamur sebesar 4-9\% sedangkan serat tidak larut sebesar 22-30\% (Kalac, 2012). Jenis serat yang banyak terkandung pada jamur seperti kitin dan juga terdapat beberapa polisakarida lainnya seperti hemiselulosa dan pektik. Serat yang semakin tinggi akan mencegah hilangnya air. Hal ini dikarenakan serat akan meningkatkan kemampuan mengikat air sehingga cooking loss menurun (Chatli, 2011).

\section{Kenampakan Irisan}

Kenampakan irisan merupakan salah satu untuk melihat kualitas sosis secara visual. Semakin kasar dan tidak kompak kenampakan sosis menunjukkan kualitas sosis yang baik. Kenampakan irisan sosis jamur tiram dan otak sapi ditujukkan pada Gambar 4.
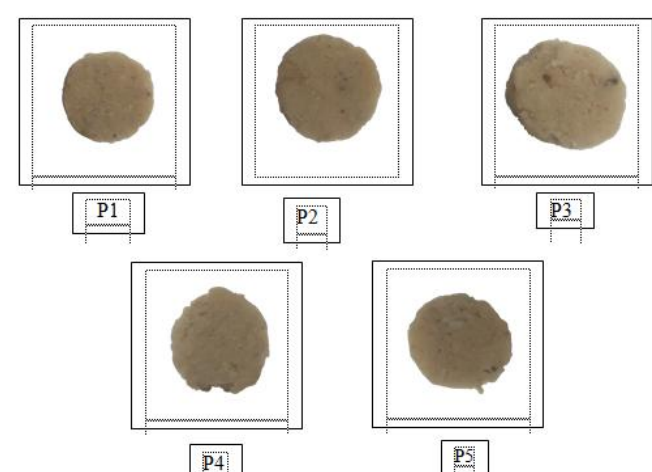

Gambar 4. Kenampakan Irisan Sosis Campuran Jamur Tiram dan Otak Sapi. P1 (Jamur tiram putih : Otak sapi $=90: 10 ; \mathrm{P} 2=$ 80:20; P3 = 70:30; P4 = 60:40; P5 = $50: 50)$

Pengamatan visual kenampakan sosis menggunakan metode pemotretan. 
Pada Gambar 4 menunjukkan perlakuan dengan kenampakan irisan dari halus sampai kasar. Kenampakan irisan sosis paling halus dan kompak adalah pada perlakuan P1 (rasio jamur tiram dan otak sapi $=$ 90:10). Kenampakan irisan dipengaruhi oleh kadar lemak dan kadar serat. Kadar lemak akan mempengaruhi kenampakan irisan. Semakin tinggi otak sapi maka akan meningkatkan kandungan lemak pada sosis (Gambar 6). Kandungan lemak yang semakin tinggi akan mengakibatkan kenampakan irisan semakin tidak halus. Hal ini dikarenakan lemak mengandung kristal besar. Kristal terikat satu sama lain oleh gaya tarik menarik Van der Waals (DeMan, 1997). Semakin tinggi otak sapi maka kenampakan irisan semakin tidak halus.

Kandungan serat akan mempengaruhi kenampakan irisan. Kandungan serat pada jamur sebesar 3,4\% (Lee et al., 2008). Kandungan serat pada jamur tiram memiliki kemampuan mengikat air sehingga menyebabkan permukaan sosis yang dihasilkan halus dan kompak.

\section{Sifat Kimia Sosis}

\section{Kadar air}

Hasil analisa kadar air sosis antara 60,31-68,61\% ditujukkan pada Gambar 5. Kadar air sosis tertinggi pada perlakuan P1 (rasio penambahan jamur tiram dan otak sapi = 90:10). Nilai terendah pada perlakuan P5 (rasio penambahan jamur tiram dan otak sapi $=50: 50)$. Berdasarkan analisis ragam pada taraf $5 \%$ dapat diketahui bahwa rasio antara jamur tiram dan otak sapi berpengaruh nyata terhadap kadar air.

Pada Gambar 5 dapat diketahui bahwa semakin tinggi rasio otak sapi maka menurunkan kadar air sosis campuran jamur tiram dan otak sapi. Kadar air sosis dipengaruhi oleh kandungan air, kandungan lemak dan kandungan serat. Penurunan kadar air sosis disebabkan karena menurunya rasio penambahan jamur tiram. Menurut Lee et al. (2008) kandungan air jamur tiram sebesar $86 \%$ sedangkan kandungan air pada otak sapi sebesar 78,9\% (Nio, 2012). Semakin tinggi jamur tiram putih maka akan menghasilkan kadar air yang semakin tinggi. Sesuai dengan penelitian Witanto (2013), penambahan jamur tiram putih yang tinggi akan menyebabkan kadar air produk sosis jamur tiram juga akan tinggi.

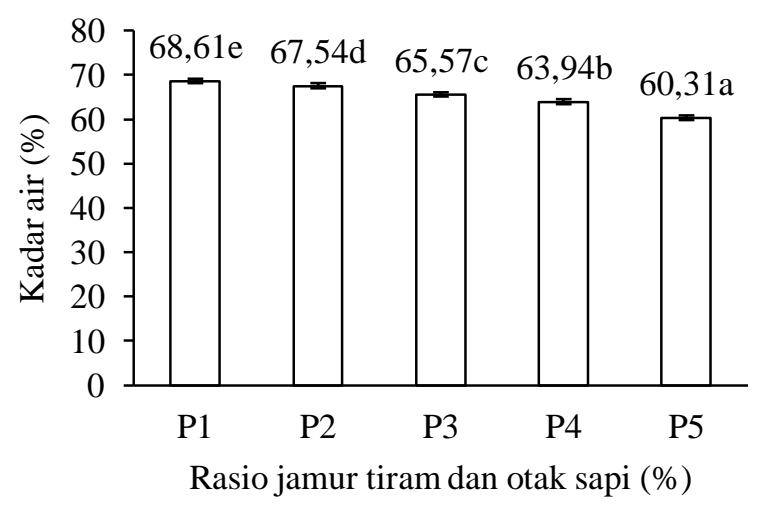

Gambar 5. Kadar air sosis campuran jamur tiram dan otak sapi. (Jamur tiram putih : Otak sapi; P1 = 90:10; P2 = 80:20; $\mathrm{P} 3=70: 30 ; \mathrm{P} 4=60: 40 ; \mathrm{P} 5=50: 50$ )

Kadar air juga dipengaruhi oleh kandungan lemak. Semakin tinggi otak sapi maka akan meningkatkan kandungan lemak (Gambar 6). Semakin tinggi kandungan lemak maka akan menurunkan kemampuan mengikat air sehingga kadar air menurun (Chun et al., 2003). Semakin tinggi otak sapi maka akan menurunkan kadar air pada sosis campuran jamur tiram dan otak sapi.

Kandungan serat juga akan mempengaruhi kadar air. Semakin tinggi otak sapi maka akan menurunkan kandungan serat pada sosis. Kandungan serat larut pada jamur sebesar 4-9\% sedangkan serat tidak larut sebesar 22-30\% (Kalac, 2012). Jenis serat yang banyak terkandung pada jamur seperti kitin dan juga terdapat beberapa polisakarida lainnya seperti hemiselulosa dan pektik. Serat yang semakin tinggi akan mencegah 
hilangnya air. Hal ini dikarenakan serat akan meningkatkan kemampuan mengikat air sehingga kadar air meningkat (Chatli et al., 2011). Kadar air sosis maksimal 67\%, sehingga terdapat 3 formula sosis yang memenuhi kadar air standar SNI (1995) yaitu P3 (rasio penambahan jamur tiram dan otak sapi 70:30); P4 (rasio penambahan jamur tiram dan otak sapi 60:40) dan P5 (rasio penambahan jamur tiram dan otak sapi 50:50) sedangkan terdapat 2 perlakuan yang tidak memenuhi standar SNI yaitu P1 (rasio penambahan jamur tiram dan otak sapi 90:10) dan P2 (rasio penambahan jamur tiram dan otak sapi 80:20).

\section{Kadar Lemak}

Hasil analisis kadar lemak sosis berkisar 1,38-4,22\%. Kadar lemak sosis tertinggi pada perlakuan P5 (rasio penambahan jamur tiram putih dan otak sapi 50:50). Kadar lemak terendah terdapat pada perlakuan P1 (rasio penambahan jamur tiram putih dan otak sapi 90:10). Berdasarkan analisis ragam pada taraf 5\% dapat diketahui bahwa rasio antara jamur tiram dan otak sapi berpengaruh nyata terhadap kadar lemak sosis. Nilai rata-rata kadar lemak dapat dilihat pada Gambar 6.

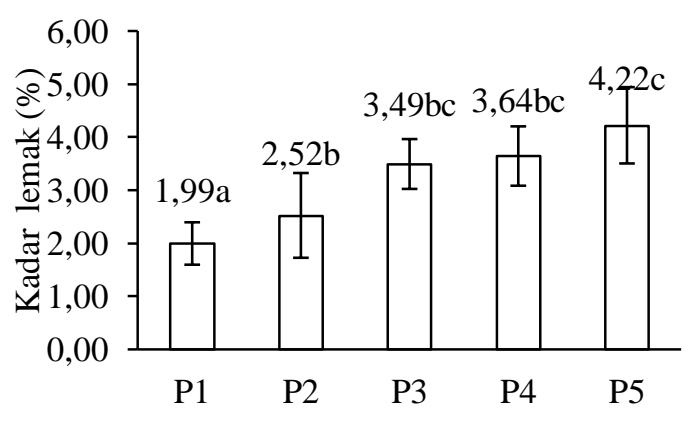

Rasio jamur tiram dan otak sapi (\%)

Gambar 6. Kadar lemak sosis campuran jamur tiram dan otak sapi. (Jamur tiram putih : Otak sapi; P1 = 90:10; P2 = 80:20; P3 $=70: 30 ; \mathrm{P} 4=60: 40 ; \mathrm{P} 5=50: 50$ )

Semakin tinggi rasio otak sapi maka akan meningkatkan kadar lemak sosis campuran jamur tiram dan otak sapi.
Peningkatan kadar lemak sosis disebabkan karena meningkatnya rasio penambahan otak sapi. Menurut Lee et al. (2008), kandungan lemak jamur tiram sebesar $0,68 \%$ sedangkan kandungan lemak pada otak sapi dalam sebesar 8,6\% (Nio, 2012). Kandungan lemak otak sapi yang lebih tinggi daripada jamur tiram akan meningkatkan kandungan lemak seiring dengan meningkatnya rasio otak sapi. Kadar lemak sosis maksimal 25\%, sehingga semua perlakuan memenuhi standar SNI No. 01-3820-1995 tentang kadar lemak sosis.

\section{Sifat Organoleptik Sosis Warna}

Warna merupakan salah satu aspek yang dapat mempengaruhi penilaian konsumen terhadap produk. Warna berasal dari warna alami dan warna yang diperoleh dari proses pengolahan. Nilai kesukaan warna sosis berkisar 5,6-6,08 (netralsedikit suka). Nilai kesukaan tertinggi pada perlakuan P1 (rasio penambahan jamur tiram dan otak sapi 90:10). Nilai kesukaan terendah pada perlakuan P5 (rasio penambahan jamur tiram dan otak sapi 50:50). Hasil uji kesukaan warna sosis terdapat pada Gambar 7.

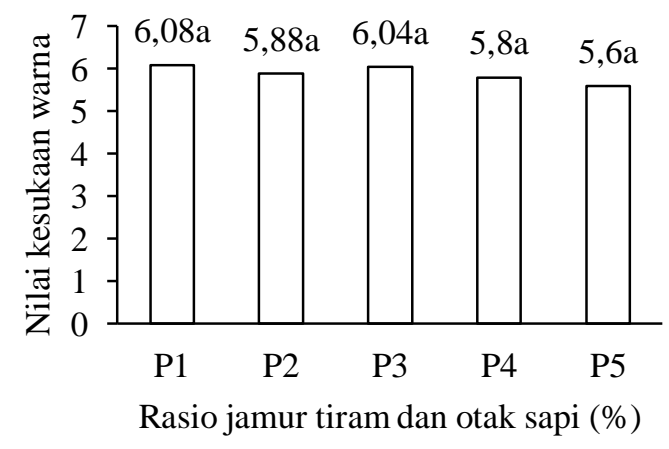

Gambar 7. Nilai kesukaan warna sosis campuran jamur tiram dan otak sapi. (Jamur tiram putih : Otak sapi; P1 = 90:10; P2 = $80: 20$; P3 = 70:30; P4 = 60:40; P5 = 50:50)

Nilai kesukaan warna tertinggi pada perlakuan P1 (rasio jamur tiram dan otak sapi 90:10). Warna sosis yang disukai nilai 
lightness tertinggi yaitu 61,54. Panelis cenderung menyukai sosis dengan warna yang cerah. Warna sosis yang dihasilkan dengan meningkatnya penambahan otak sapi menyebabkan menurunnya tingkat kesukaan meskipun hasil analisa sidik ragam tidak berbeda nyata.

\section{Aroma}

Aroma merupakan salah satu aspek yang dapat mempengaruhi penilaian konsumen terhadap produk. Dalam industri pangan, uji aroma sangat penting karena dapat memberikan hasil penilian penerimaan konsumen terhadap produk yang dihasilkan dengan cepat. Nilai kesukaan aroma sosis berkisar 5,4-6,36 (netral-sedikit suka). Nilai kesukaan tertinggi pada perlakuan P5 (rasio penambahan jamur tiram dan otak sapi 50:50). Nilai kesukaan terendah pada perlakuan P1 (rasio penambahan jamur tiram dan otak sapi 90:10). Hasil uji kesukaan aroma sosis terdapat pada Gambar 8.

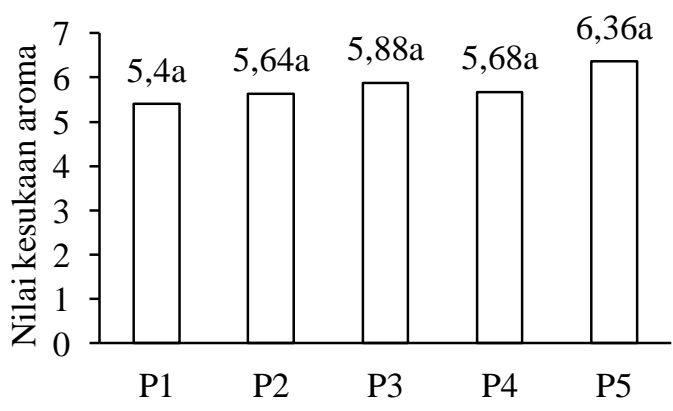

Rasio jamur tiram dan otak sapi (\%)

Gambar 8. Nilai kesukaan aroma sosis campuran jamur tiram dan otak sapi. (Jamur tiram putih : Otak sapi, P1= 90:10; $\mathrm{P} 2=$ $80: 20 ; \mathrm{P} 3=70: 30 ; \mathrm{P} 4=60: 40 ; \mathrm{P} 5=$ 50:50)

Rasio jamur tiram dan otak sapi tidak berbeda nyata terhadap kesukaan aroma sosis. Aroma dipengaruhi oleh kandungan lemak serta adanya senyawa volatil pada bahan. Kandungan lemak pada otak sapi sebesar 8,6\% (Nio, 2012). Penambahan otak sapi akan meningkatkan nilai kesukaan aroma meskipun tidak berbeda nyata. Hal ini dikarenakan pada proses pemanasan lemak mencair bahkan menguap menjadi komponen lain seperti flavor yang akan disukai panelis (Sundari et al., 2015).

\section{Tekstur}

Tekstur merupakan salah satu aspek yang dapat mempengaruhi penilaian konsumen terhadap produk. Tekstur akan memberikan informasi tentang kelembutan makanan, bentuk permukaan pada makanan serta keadaan makanan (kering, basah dan lembab). Nilai kesukaan tekstur sosis berkisar 5,04-5,36 (netral). Nilai kesukaan tertinggi pada perlakuan P1 (rasio penambahan jamur tiram dan otak sapi 90:10). Nilai kesukaan terendah pada perlakuan P5 (rasio penambahan jamur tiram dan otak sapi 50:50). Hasil uji kesukaan tekstur sosis terdapat pada Gambar 9.

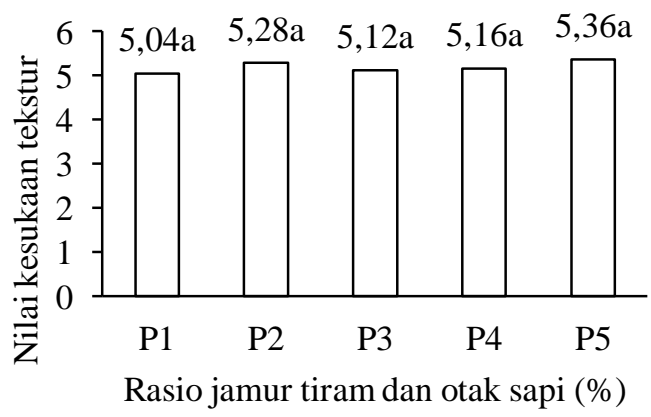

Gambar 9. Nilai kesukaan tekstur sosis campuran jamur tiram dan otak sapi. (Jamur tiram putih : Otak sapi; P1 = 90:10; P2 = 80:20; P3 = 70:30; P4 = 60:40; P5 = 50:50)

Rasio jamur tiram dan otak sapi tidak berbeda nyata terhadap kesukaan tekstur sosis. Tekstur dengan rheotex sosis yang paling disukai yaitu P5 (rasio penambahan jamur tiram dan otak sapi 50:50) memiliki nilai kekerasan tertinggi yaitu $63 \mathrm{~g} / 1,5 \mathrm{~mm}$. Panelis cenderung menyukai sosis dengan tekstur yang cukup keras. Semakin tinggi penambahan otak sapi maka akan meningkatkan kesukaan tekstur sosis 
campuran jamur tiram putih dan otak sapi meskipun tidak berbeda nyata.

\section{Rasa}

Rasa merupakan sebuah reaksi kimia dari gabungan berbagai bahan makanan dan menciptakan sesuatu rasa baru yang dirasakan oleh lidah. Atribut ini banyak ditentukan oleh formulasi yang digunakan dan tidak dipengaruhi pengolahan (Winarno, 2004). Nilai kesukaan rasa sosis berkisar 5,32-5,75 (netral). Nilai kesukaan tertinggi pada perlakuan P5 (rasio penambahan jamur tiram dan otak sapi 90:10). Nilai kesukaan terendah pada perlakuan P3 (rasio penambahan jamur tiram dan otak sapi 70:30). Hasil uji kesukaan rasa sosis terdapat pada Gambar 10.

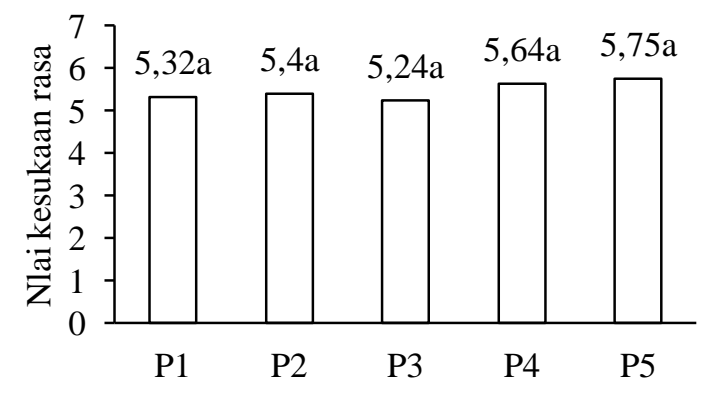

Rasio jamur tiram dan otak sapi $(\%)$

Gambar 10. Nilai kesukaan rasa sosis campuran jamur tiram dan otak sapi. (Jamur tiram putih : Otak sapi; P1 $=90: 10$; $\mathrm{P} 2=80: 20 ; \mathrm{P} 3=70: 30 ; \mathrm{P} 4=60: 40$; $\mathrm{P} 5=50: 50$ )

Rasio jamur tiram dan otak sapi tidak berbeda nyata terhadap kesukaan rasa. Salah satu faktor yang mempengaruhi rasa adalah kandungan lemak. Kandungan lemak pada otak sapi dalam sebesar 8,6\% (Nio, 2012). Lemak akan memberikan rasa gurih dan aroma yang spesifik sehingga akan meningkatkan tingkat kesukaan panelis. Berdasarkan hasil analisa kadar lemak sosis campuran jamur tiram dan otak sapi yang paling disukai yaitu P5 (rasio penambahan jamur tiram dan otak sapi 50:50) mengandung kadar lemak sebesar 4,22\%. Oleh karena itu, semakin tinggi penambahan otak sapi maka akan meningkatkan kesukaan rasa meskipun tidak berbeda nyata.

\section{Keseluruhan}

Keseluruhan terhadap penilaian kesukaan pada sosis jamur tiram putih dan otak sapi secara organoleptik meliputi warna, rasa, aroma, dan tekstur. Hasil uji kesukaan keseluruhan dapat dilihat pada Gambar 11.

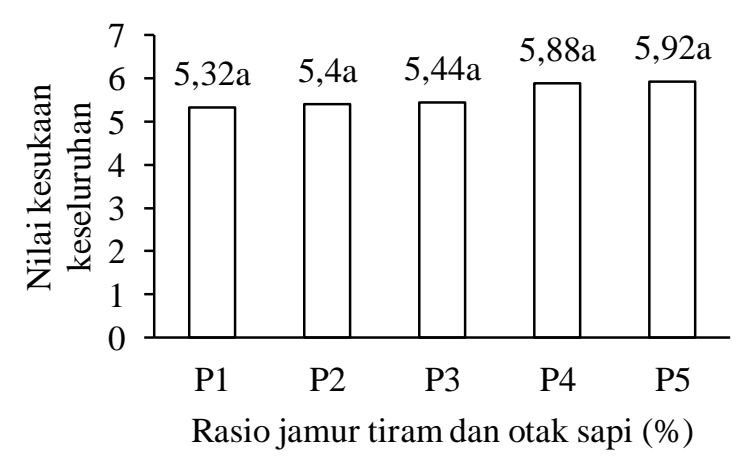

Gambar 11. Nilai kesukaan keseluruhan sosis campuran jamur tiram dan otak sapi. (Jamur tiram putih : Otak sapi; P1 = 90:10; P2 = 80:20; $\mathrm{P} 3=70: 30 ; \mathrm{P} 4=$ $60: 40 ; \mathrm{P} 5=50: 50$ )

Nilai kesukaan keseluruhan sosis ditujukkan pada Gambar $\mathbf{1 1}$ berkisar antara 5,32-5,92 (netral-sedikit suka). Nilai kesukaan keseluruhan sosis tertinggi terdapat pada perlakuan P5 (rasio penambahan jamur tiram putih dan otak sapi $=50: 50)$ yaitu 5,92 (sedikit suka), sedangkan nilai kesukaan terendah pada perlakuan P1 (rasio penambahan jamur tiram putih dan otak sapi $=90: 10$ ) yaitu 5,32 (netral). Berdasarkan analisis ragam pada taraf $5 \%$ menunjukkan bahwa rasio jamur tiram dan otak sapi tidak berbeda nyata terhadap kesukaan keseluruhan sosis. Kesukaan keseluruhan ditentukan oleh kesukaan rasa, aroma dan tekstur.

\section{Perlakuan Terbaik}

Uji efektivitas merupakan uji yang digunakan untuk mengetahui perlakuan terbaik dari masing-masing perlakuan berdasarkan hasil uji organoleptik yang 
meliputi warna, aroma, rasa, tekstur, kesukaan keseluruhan dan sifat fisik yaitu cooking loss. Hasil uji efektivitas menunjukkan bahwa perlakuan terbaik terdapat pada perlakuan P5 (rasio jamur tiram dan otak sapi 50:50). Hasil uji efektivitas sosis campuran jamur tiram putih dan otak sapi dapat dilihat pada Tabel 1.

Tabel 1. Nilai efektivitas

\begin{tabular}{lc}
\hline Perlakuan & Nilai efektivitas \\
\hline P1 & 0,36 \\
P2 & 0,50 \\
P3 & 0,37 \\
P4 & 0,48 \\
P5 & 0,67 \\
\hline
\end{tabular}

\section{Hasil Analisis Proksimat Sosis Jamur Tiram dan Otak Sapi}

Perlakuan P5 untuk kadar air, kadar lemak, kadar abu dan kadar protein sesuai SNI, namun kadar karbohidrat tidak sesuai SNI. Perbandingan kandungan sosis perlakuan terbaik dengan standar SNI No. 01-3820 (BSN, 1995) dapat dilihat pada Tabel 2.

Tabel 2. Perbandingan kandungan sosis perlakuan terbaik dengan standar SNI

\begin{tabular}{lcc}
\hline \multicolumn{1}{c}{ Parameter } & $\begin{array}{c}\text { Perlakuan } \\
\text { Terbaik }(\%)\end{array}$ & $\begin{array}{c}\text { Standar SNI } \\
\text { No. 01-3820 } \\
(\%)\end{array}$ \\
\hline Kadar Air & 60,31 & Maks 67,0 \\
Kadar Lemak & 4,22 & Maks 25,0 \\
Kadar Protein & 21,05 & Min 13,0 \\
Kadar Abu & 2,08 & Maks 3,0 \\
Kadar Karbohidrat & 12,34 & Maks 8 \\
\hline
\end{tabular}

\section{KESIMPULAN}

Formula terbaik pada perlakuan P5 (rasio penambahan jamur tiram dan otak sapi $=50: 50)$. Sosis yang dihasilkan mempunyai nilai tekstur $63 \mathrm{~g} / 1,5 \mathrm{~mm}$; nilai warna (lightness) 57,59; cooking loss 7,11\%; kadar air 60,31\%; kadar lemak 4,22\%; kadar protein 21,05\%; kadar abu 2,08\%; kadar karbohidrat 12,34; kesukaan warna, aroma, tekstur, rasa dan keseluruhan berturut-turut 5,6;6,36; 5,36; 5,$75 ; 5,92$ (netral- sedikit suka).

\section{DAFTAR PUSTAKA}

Anderson, B, A. 1988. Compositian and Nutrition value of edible meat byproduct. Advance in Meat Research, 15 (43): 64-67.

AOAC (Association of Official Agricultural Chemist). 2005. Official Methods of Analysis of The Association of Official Agriculture Chemist $16^{\text {th }}$ edition. Virginia.

Apriliyani, M. W. 2010. "Pengaruh Penggunaan Tepung Tapioka dan Carboxymethyl Cellulose (CMC) pada Pembuatan Keju Mozzarella Terhadap Kualitas Fisik dan Organoleptik". Skripsi. Universitas Brawijaya, Malang.

Badan Standar Nasional. 1995. SNI Sosis Daging. No 01-3820-1995. Badan Standart Nasional Indonesia, Jakarta.

Cakli, S. and Dincer., M., T. 2015. Textural acceptability of preapred fish sausages by controlling textural indicator. Turkish Journal of Veterinary and Animal Science, 39: 364-368.

Chandra. 2015. "Pengaruh Penggunaan Berbagai Konsentrasi Angkak Terhadap Daya Awet Sosis Sapi”. Skripsi. Universitas Padjajaran Bandung.

Chatli, K., Biswas, A, K., Kumar, V., Bhosle, S. 2011. Dietary fibers as functional ingredients in meat products and their role in human health. International Journal of Livestock Production, 2 (4): 45-54.

Chun, S,S., Koo, B,C., Hye, L, L. 2003. Product characteristics of comminuted sausages as affected by various fat and moisture combinations. Asian-Aust. J. Anim. Sci., 17 (4): 500-600.

De Garmo, E. P., Sullivan, W. G., dan Canada, J. R. 1984. Engineering Economy. Macmillan Publishing Company, New York.

DeMan, J.M. 1997. Kimia Makanan. Institut Teknologi Bandung, Bandung. 
Garry, D, J., Pradeep, P, a., Mammen., John, M, S., Sean, C, Goestsch, S., Clay Williams., James, A, R., Mary, G., Garry. 2002. Neuroglobin: A Novel Member of the globin family, is expressed in focal regions of the brain. The Journal of Histochemistry and Cytochemistry, 50 (12): 1591-1598.

Jensen, Donald, and Thomas. 1958. Purification and identification of brain phospholipides associated with thromoboplastic activity. Journal Biol. Chem, 233 (5): 83-86.

Kalac, P. 2012. Chemical Composition and nutritional value of european spices of wild growing mushrooms: Nova Science Publishers. ISBN 978-1-61470-110-1.

Lee, T, S., Nuhu, A., Ruhul, A., Asaduzzaman,K., Ismot, A., Mi, J, S., Min, W, L. 2008. Nutritional analysis of cultivated mushrooms in Bangladesh Pleurotus ostreatus, Pleurotus sajurcaju, Pleurotus florida and Calocybe indica. Korean Society of Mycology, 36 (4): 228-232.

Mabesa, L.B. 1986. Sensory Evaluation of Foods: Principles and Methods. College of Agricultural. University of the Philippines, Los Banos.

Maulana, E. 2012. Panen Jamur Tiap Musim Panduan Lengkap Bisnis dan Budidaya Jamur Tiram. Lily Publisher, Yogyakarta.

Nio, O. K. 2012. Daftar Analisis Bahan Makanan. Fakultas Kedokteran Universitas Indonesia, Jakarta.

Setyowati, M.T. 2002. "Sifat Fisik, Kimia dan Palatabilitas Nugget Kelinci, Sapi, Ayam yang Menggunakan Berbagai Tingkat Konsentrasi Tepung Maizena". Skripsi. Institut Pertanian Bogor, Bogor.

Soeparno. 2005. Ilmu dan Teknologi Daging. Gadjah Mada University Press, Yogyakarta.

Sundari, D., Amasyhuri., dan Astuti, L. 2015. Pengaruh proses pemasakan terhadap komposisi zat gizi bahan pangan sumber protein. Media Litbangkes, 25 (4): 4347.
Widati, A. S., Mochamad. S., Djalala, R. 2013. Studi tentang penambahan jamur tiram (Pleurotus ostreatus) terhadap tekstur dan organoleptik chicken nuggets. Jurnal Ilmu Teknologi Hasil Ternak, 8 (2): 28-34.

Winarno, F, G. 2004. Kimia Pangan dan Gizi. Gramedia Pustaka Utama, Jakarta.

Witanto, B. 2013. "Pembuatan Sosis Jamur Tiram Putih dan Tepung Rebung dengan Kombinasi Tepung Tapioka dan dan Karaginan (Eucheuma cottoni Doty)". Skripsi. Universitas Atma Jaya Yogyakarta, Yogyakarta. 